\title{
Particularities of Conflict of Interest Legal Regulation in the Civil Service System
}

\author{
Kichaluk O.N.* Morozova O.A.
}

\author{
Institute of Service and Entrepreneurship (branch) of Don State Technological Institute in the city of Shakhty, Shakhty, \\ 346500 Russia \\ *Corresponding author. Email: olga.kichalyuk@mail.ru
}

\begin{abstract}
The article analyzes the significant particularities of the legal regulation of the conflict of interest institution in the system of civil and municipal service. A comprehensive research of this institution from a legal point of view is significant for solving issues arising in the process of its legislative regulation. The objective of science is to find the most effective settlement models and ways to prevent a conflict of interest in civil and municipal services. Moreover, the existing problems of applying anti-corruption legislation practices in the field of conflict of interest settlement are examined, and possible solutions are proposed. Establishing the direct supervisor's responsibility for the unlawful conduct of his subordinates obliges to identify facts indicating a conflict of interest. Personnel departments within their competence (divisions for prevention of violations) take part in the work to prevent and eliminate conflicts of interest. All government organizations establish commissions on compliance with the requirements for official conduct and conflict of interest settlement, granted with a wide range of powers, including the observance by officers of restrictions and prohibitions that contribute to the conflicts of interest prevention and settlement, and to the implementation of measures to prevent corruption.
\end{abstract}

Keywords: conflict of interests, civil service, the reform concept, legal regulation, corruption

\section{INTRODUCTION}

The relevance of the topic is due to the ongoing active processes in the Russian Federation to modernize the government control system and increase the effectiveness of civil service functioning, an integral part of which is the development of ways to resolve managerial "anomalies" and conflicts.

The appearance of the "conflict of interest" concept in the official documents is associated with the adoption of the Concept of Civil Service System Reform, where the focus was on the reasons for conflict of interest mechanism formation that affects the performance of official duties by officials [10].

In our view, the conflict of interests is more successfully characterized by additional explanations contained in paragraph 5 of Art. 8 of the United Nations Convention against Corruption (hereinafter - UNCAC), approved by the Resolution of the General Assembly on October 31, 2003, and ratified by the Russian Federation on March 8, 2006. The UNCAC invites states parties to "to establish measures and systems requiring public officials to make declarations to appropriate authorities regarding, inter alia, their outside activities, employment, investments, assets and substantial gifts or benefits from which a conflict of interest may result with respect to their functions as public officials." [2].
The Russian Federation fulfilled this obligation by determining the definition and procedure for "conflict of interest" settlement in Articles 10, 11 of the Federal Law "On Combating Corruption" (hereinafter referred to as the Law) [3]. However, the "conflict of interest" construction as amended by the Law of 2015, expanding the concept of the conflict of interest components, has left provisions that are, in our opinion, difficult for understanding.

The goal of the National Anti-Corruption Plan for 20182020 is to ensure a uniform application of legislation on combating corruption offenses in order to increase the effectiveness of mechanisms to prevent and settle conflicts of interest in the civil service system [7].

\section{RESEARCH METHODOLOGY}

The methodological framework of research was the general philosophical methods of scientific cognition, based on the principles of objectivity and comprehensiveness, as well as general scientific (analysis and synthesis, the logical method) and special methods statistical, modeling and others.

Through them, including using private scientific methods of cognition (linguistic-legal, formal-dogmatic, comparative law), the general trends in the government's 
anti-corruption policy formation and its specific features in different countries are determined.

The theoretical framework of research is presented by scientific works devoted to the analysis of legal relations arising in the process of settling a conflict of private and public interests in the system of public administration and combating corruption, as well as the practice of their implementation. These include the works of Russian jurists as V. N. Ageev, O. R. Azhirbaeva, T. Yu. Ampleeva, N. Kh. Akhmetshin, I. L. Bachilo, T. V. Beken, I. I. Bikeev, Yu. V. Vasiliev, B.V. Volzhekin, Yu. A. Voronin, L. E. Gaukhman, I. I. Gilinsky, K. I. Golovshchinsky, Yu. V. Golik, V. S. Davydov, S. A. Denisov, P. A. Kabanov, V. I. Karasev, A. V. Kurakin, V. V. Lunev, C. V. Maksimov, P. A. Skoblikov et al. The regulatory framework of research includes the Constitution of the Russian Federation, 1993, federal constitutional laws, federal laws, international acts affecting anticorruption policy issues.

The theoretical and practical relevance of the research is to conduct a comparative legal analysis of combating corruption offenses in Russia and abroad. The research results can serve as a scientific framework:

- in domestic anti-corruption legislation modernization;

- for practical improvement of the conflicts of interest settlement.

\section{RESEARCH RESULTS}

Concept of the "conflict of interest" formulated in Art. 10 of the Law is defined as "a situation in which the selfinterest (direct or indirect) of a person who is taking a position that provides for the obligation to take measures to prevent and settle a conflict of interest, affects or may affect the proper, objective and impartial execution of his official (employment) duties (exercise of authority) "[3]. In Russia, the legitimization of anti-corruption measures as a direction of the entire system of government bodies began after the President issued two decrees:

1) No. 361 "On Struggle Against Corruption in the State Service System" dated April 4, 1992;

2) No. 305 "On the priority measures for preventing corruption and reducing the budgetary expenses in the organization of the purchase of products for the state needs" dated April 8, 1997.

Subsequently, these acts formed the basis of the Federal Law No. 119-FZ "On the Foundations of the Civil Service of the Russian Federation" dated July 31, 1995, which became invalid in 2004 .

Since 2008, after the adoption of a number of program anti-corruption documents defining the main directions of the government anti-corruption policy and at the same time reflecting the fulfillment of Russia's obligations to implement the provisions of the UNCAC and the Council of Europe Convention in the Russian legal system, the fight against corruption takes on the character of long term goals of the state.

The Federal Law "On Combating Corruption”, adopted 15 years after the adoption of the Constitution of the Russian Federation, contains a legal definition of corruption, establishes the basic principles for combating corruption, legal and organizational principles for preventing and combating corruption, minimizing and eliminating the consequences of corruption offenses. Its adoption necessitated the modification of other regulatory legal acts. The relevant changes affected the legal status of judges, deputies of the Russian parliament, members of the Accounts Chamber of the Russian Federation, employees of the Central Bank of Russia, elected officials of local governments.

Nowadays, in the Russian Federation, the fight against corruption has a state ideological basis with clearly set goals to eradicate the causes and facts of corruption.

For now, it is certain that anti-corruption legislation has been formed and meets not only the requirements of international anti-corruption standards but stands toe to toe to the best foreign legislative practices.

The Constitution of the Russian Federation is the first among the legal frameworks to combat corruption listed in the Law, and, according to part 1 of Art. 15, has the supreme legal force and direct effect [1]. The judgment by the Plenum of the Supreme Court of the Russian Federation No. 8 "On Certain Issues of Application of the Constitution of the Russian Federation by the Courts during Administration of Justice" dated October 31, 1995, defines the procedure for application of this constitutional provision by the courts [8].

A special role in shaping the government anti-corruption policy is assigned to acts of the President of the Russian Federation, which were approved, including national anticorruption plans.

Administrative regulations are essential in implementing measures to combat corruption in federal executive bodies. They were developed and adopted by the federal executive bodies on the basis of the Decree of the Government of the Russian Federation No. 452 "On Standard Regulations of Internal Organization of Federal Executive Power Bodies" dated July 27, 2005 [9].

For a long time corruption in Russia was mostly considered from the criminal and administrative law but after the ratification of UNCAC by the Russian Federation in March 2006, our country has undertaken to bring certain labor laws in line with the requirements of this Convention.

So, according to Art. 12 of the Federal Law "On Combating Corruption" and Art. 64.1 of the Labor Code of the Russian Federation (LC of the RF), citizens who have taken the positions of civil or municipal service, the list of which is established by the regulatory legal acts of the Russian Federation, after leaving the civil or municipal service for two years, upon conclusion of employment contracts, are obliged to inform the employer about the last place of service. Corresponding duties are entrusted to 
employers by the art. 64.1 of the Labor Code of the Russian Federation [6].

\section{DISCUSSING THE RESULTS}

A significant problem, in our opinion, is the lack of a systematic approach to regulating relations concerning the anti-corruption in the municipalities. Very often municipalities accept only individual acts on this issue. So, at the municipal level, the organization and implementation of the municipal commissions' activities on combating corruption are far from always regulated. In the practice of municipal rulemaking, there are cases when this sphere of legal regulation in relation to a specific municipality is limited only by the adoption of an act determining this commission composition.

For this reason, it makes sense to develop an approximate list of municipal legal acts on anti-corruption issues recommended for adoption in municipalities at the level of methodological support in the constituent entities of the Federation.

It seems necessary to pay special attention to two factors affecting the increase in the conflict potential of the civil and municipal services regarding the occurrence of a conflict of vested interests.

These factors are:

1) prerequisites for a conflict in any government body due to systemic conditions (they are caused, inter alia, by the imperfection and inconsistency of the legislative framework governing civil and municipal services);

2 ) the absence of so-called "merit system" with elements of prohibitions in the government bodies.

A real conflict of vested interests that has arisen and proceeds in the government body does not have such a stage of development at which the employer's representative, within the current legislation, can make a managerial decision aimed at overcoming the conflict by terminating the service contract with the civil officer.

Such a "scenario" is permissible only in cases of a conflict of vested interests in municipal institutions. Thus, according to the Federal Law "On Municipal Service in the Russian Federation", "failure to take measures to prevent or settle a conflict of interest by a municipal officer who is a party to a conflict of interest is an offense involving the dismissal of a municipal officer from the municipal service" [4].

Theory of conflict qualifies such an end to the conflict interaction of the social relations parties as a forceful settlement of the conflict. But in this context, we are more concerned about the problem of insecurity of an individual who is on municipal service from dismissal in some cases that may arise during the application of this law. The following situations can be attributed to these cases: when, for objective reasons, the conflict of interest will be illusory, or when the municipal officer, for objective reasons, cannot independently take appropriate measures to prevent or settle this conflict.
What principles should be followed by the employer's representative in the conflict of interest in its government body in its legal meaning?

Literature notes, it is advisable to be guided by the principle of "developing the rules of conflict behavior of a civil officer recognized by both parties, determining the consequences and results of official behavior" [11].

That is, it is foreseen to practice the negotiation process, as a result of which the rules of conflict behavior recognized by both parties can be developed. We agree with the opinion that this proposal is difficult to accept for several reasons.

Firstly, in the event of a conflict of interest in the government body, a rule is established according to which the employer's representative should take appropriate measures "up to the dismissal of a civil officer who is a party to a conflict of interest from civil service in the manner established by this Federal Law" [11].

Secondly, the civil officer is obliged to obey the rules of law governing his behavior in any situations and he does not have the right to negotiate with the employer's representative. For the very reason it is difficult to sign up to some authors' position who believe that if an individual personnel dispute arises in a government body, such an authority with jurisdiction as a commission for these disputes consideration may intervene if the following condition is met. It (a condition) is the failure of a civil officer's attempt, independently or with his representative participation, to settle discrepancies underlying the conflict through direct negotiations with the employer's representative [12].

Is the mediation procedure appropriate for the conflict in question in terms of its effectiveness? The relevance of this issue has significantly increased after the Federal Law No. 193-FZ "On an Alternative Dispute Resolution Procedure with the Participation of a Mediator (Mediation Procedure)" dated July 27, 2010, has entered into legal force [5].

\section{FINDINGS (CONCLUSION)}

Based on the foregoing, we can make the following observations:

Firstly, the problem of triggers and course of the conflict of vested interests in government bodies is subject to investigation in several aspects:

it is necessary to understand what signs of this conflict should be the subject of consideration by such an authority with jurisdiction as the Commission on Official Conduct and the Settlement of Conflict of Interest.

it is necessary to know what steps can be particularly undertaken in practice to prevent a conflict, which, from the Russian legislator's point of view, has a corruption component.

Secondly, a real conflict of vested interests can be caused by:

- the conditions for the civil (municipal) service; 
- involvement of a civil (municipal) officer in group deviant behavior under pressure from a senior official;

- the prerequisites for the occurrence of this type of conflict in any government body due to systemic conditions, including the imperfection and inconsistency of legislation;

- poor control on the part of the personnel service of the government body over the moral character of the person entering the civil service, as well as persons already undergoing it;

- the absence of the so-called "merit system" in the government body, which has been introduced in a number of foreign countries in order to prevent corruption.

Thirdly, the parties involved in the conflict of interest requires legislative clarification. So, the legislator provides that a conflict of interest is a conflict between a person (individual) and a government body, society, the Russian Federation, a constituent entity of the Federation, or a municipality. That is, the legislator does not take into account the practice of combating corruption, during which a conflict of interest with the group of parties involved in the conflict is revealed. Note that a group refers to two or more people.

There is no clear indication of the self-interest of individual, which can actually or potentially lead to a conflict of interest. In addition, a conflict of interest as a situation is not characterized either as a struggle of the parties of interaction for material resources or as the presence of disagreements between the parties of interaction. When concretizing the "conflict of interests" term, the domestic legislator uses such a criterion as the contradictions between the self-interest of the civil (municipal) officer and the legitimate interests of citizens, organizations, society, the constituent entity of the Federation or the Russian Federation, as well as the municipality. Formally, the contradictions between the self-interest of a civil officer and the legitimate interests of at least one of these entities cannot be qualified as a conflict of interest.

The use of the "legitimate interests" category and the "causing harm to legitimate interests" expression by the legislator is legally uncertain.

It is not clear at what point does the conflict of interest begin. The legislative definition of a conflict of interest does not imply what needs to be perceived and qualified as the beginning of a real conflict.

Fourthly, a conflict of vested interests is a public disagreement between the parties of administrative and service relations within the government body in the form of initiating the process of consideration of a written statement of a civil officer by the commission for the conflict of interest settlement or a similar appeal of the employer's representative to this body on the basis of his own motives as a response to the corrupt behavior of a civil officer.

Note that the basis for starting the process of considering the deviant behavior of an individual filling the position of civil or municipal service may be the subjective decision of the employer's representative. In addition, this may be preceded by real or imaginary circumstances. Their essence lies in the use of professional opportunities and corporate information by officer in the interests of a third party, information, which the official became aware of in connection with his official duties to satisfy his private interests.

Due to the fact that the parties of administrative and service relations interact with each other as subjects of legal relations, a conflict of vested interests can be defined in two ways: as disagreements between subjects of legal relations regarding differently understood mutual rights and obligations, or differently understood moral principles of behavior in the implementation of civil services in connection with their alleged violation of a real or illusory corruption nature, and challenging them in the process of law enforcement of applicable law;

That is, the essence of work with a conflict comes down to considering the causes and subject of the conflict, identifying the right and wrong side, and making a decision by the relevant judicial authority. Herewith, the conflict ends after the entry into force of the court decision and private rulings addressed to the parties to this conflict. Thus, a conflict of interest is defined by the legislator as the influence of the self-interest of the civil (municipal) officer on the objective performance of his duties, which leads or may lead to a contradiction between the selfinterest of the civil (municipal) officer and the legitimate interests of citizens, organizations, society, the constituent entity of the Federation or the Russian Federation, as well as the municipality.

Conflict settlement is the process of considering the causes and subject of open real conflict interaction between parties to social relations, performed by the relevant administrative or judicial bodies representing the interests of the state and rightfully capable to make an appropriate decision to this or that subject of this interaction, and also, if necessary, to achieve coercion to enforce this decision.

\section{REFERENCES}

[1] Konstituciya Rossijskoj Federacii: (prinyata vsenarodnym golosovaniem 12.12.1993) [s uchyotom popravok, vnesennyh Zakonami RF o popravkah $\mathrm{k}$ Konstitucii RF ot 30.12.2008 No. 6-FKZ, ot 30.12.2008 No. 7-FKZ, ot 05.02.2014 No. 2-FKZ, ot 21.07.2014 No. 11-FKZ] // Sobranii zakonodatel'stva RF. - 04.08.2014. - No. 31. - St. 4398.

[2] Konvenciya Organizacii Ob"edinennyh Nacij protiv korrupcii: [zaklyuchena v g. N'yu-Jorke 2003 g.] [Elektronnyj resurs] // URL: https://www.un.org/ru/documents/decl_conv/conventio $\mathrm{ns} /$ corruption.shtml (data obrashcheniya 15.01.2020g.).

[3] O protivodejstvii korrupcii : feder. zakon : [prinyat Gosudarstvennoj Dumoj 19 dekabrya 2008 g.: odobren Sovetom Federacii 22 dekabrya 2008 g.] // Sobranie 
zakonodatel'stva RF. - 2008. - No. 52 (ch.1). $\neg$ St. 6228 .

[4] O municipal'noj sluzhbe v Rossijskoj Federacii : feder. zakon : [prinyat Gosudarstvennoj Dumoj 07 fevralya 2007g.: odobren Sovetom Federacii 21 fevralya 2007 g., s izmeneniyami na 27.12.2018 g.] // Sobranie zakonodatel'stva RF. - 2007. - No. 10. - St. 1152.

[5] Ob al'ternativnoj procedure uregulirovaniya sporov s uchastiem posrednika : feder. zakon : [prinyat Gosudarstvennoj Dumoj 07 iyulya 2010 g.: odobren Sovetom Federacii 14 iyulya 2010 g., s izmeneniyami na 26.07.2019 g.] // Sobranie zakonodatel'stva RF. 2010. - No. 31. - St. 4162.

[6] Trudovoj kodeks Rossijskoj Federacii: [prinyat Gosudarstvennoj Dumoj 21 dekabrya 2001g.: odobren Sovetom Federacii 26 dekabrya 2001 g., s izmeneniyami na 27.12.2018 g.] // Sobranie zakonodatel'stva RF. - 2002. - No. 1 (ch. 1). - St. 3.

[7] O Nacional'nom plane protivodejstviya korrupcii na 2018 - 2020 gody interesov : ukaz Prezidenta Rossijskoj Federacii ot 29 iyunya 2018 g. No. 378 // Sobranie zakonodatel'stva RF. - 2018. - No. 27. - St. 4038 .

[8] O nekotoryh voprosah primeneniya sudami Konstitucii Rossijskoj Federacii pri osushchestvlenii pravosudiya: Postanovlenie Plenuma Verhovnogo Suda RF ot 31 oktyabrya 1995 g. No. 8 // Rossijskoj gazete. 1995. - No.2.

[9] O Tipovom reglamente vnutrennej organizacii federal'nyh organov ispolnitel'noj vlasti: Postanovleniya Pravitel'stva RF ot 27 iyulya 2005 g. No. 452 // Rossijskoj gazete - 2005. - N 171

[10] Koncepciya reformirovaniya sistemy gosudarstvennoj sluzhby : ukaz Prezidenta Rossijskoj Federacii ot 15 avgusta 2001 g. No. Pr-1496 [Elektronnyj resurs] // URL: https://zakonbase.ru/content/base/59119 (data obrashcheniya 15.01.2020 g.).

[11] Solov'ev, O.V. Kadrovye tekhnologii v sisteme gosudarstvennoj sluzhby : uchebno-metodicheskoe posobie / O.V. Solov'ev. - Belgorod: Konstanta, 2009. $-153 \mathrm{~s}$.

[12] SHestakov, A.G. YUridicheskaya konfliktologiya: uchebnoe posobie / A.G. SHestakov. - Sankt-Peterburg : Izd-vo Politekhnicheskogo un-ta, 2013.-155 s. 